\title{
ROAD TRANSPORT INFORMATION SYSTEM: A PANACEA FOR ROAD TRANSPORT FACILITY MANAGEMENT IN KATSINA LOCAL GOVERNMENT, KATSINA STATE, NIGERIA
}

\author{
MUHAMMAD ZILKIFLU DABO AND SULAIMAN YUNUS \\ Department of Geography, Bayero University Kano \\ Authors email: syunus.geog@buk.edu.ng and zmdabo@yahoo.com
}

\begin{abstract}
This study aimed at examining the spatial pattern of RTF within Katsina Local Government with a view to developing a comprehensive Road Transport Facility Information System (RTFIS) to enable efficient management and planning for sustainable development. Analogue record (maps and attributes) of the existing RTF were obtained from the relevant departments, and were updated with the data obtained through field and GPS surveys, and Google Earth image (2019). QGIS 3.8 software was used for Nearest Neighbor Analysis, developing comprehensive database and series of spatial and attributes queries in order to demonstrate the capability of Geospatial technology in efficient management of RTF information. The result revealed a dispersed distribution pattern of Roundabouts within the study area with nearest neighbor ratio of 1.3 and zscore value of 2.9. It is therefore recommended that the departments involved in RTF management should embrace Geospatial technology as one of the contemporary methods for efficient managing, manipulating, retrieving and updating RTF records for sustainable urban development.
\end{abstract}

Keywords: Road Transport Facility, Nearest Neighbor Analysis, Hyperlink, Spatial Queries

\section{INTRODUCTION}

GIS-based road Transport Information System (TIS) is a product of integration of the concepts of Geographic Information System (GIS) and Transportation Information System (TIS). Winter et al. (2010) states that TIS includes the interdisciplinary fields of mobility science (data-driven modeling of human and animal dynamics using location data) and computational transportation science (the application of computer science to understand and manage transportation systems). It is therefore not hyperbole to state that there is a revolution in the human sciences, including transportation and urban sciences, fueled by a stunning advancement in capabilities to capture, store and process data, as well as communicate information and knowledge derived from these data (Miller and Shaw, 2015). Transportation is one of the fastest growing of many fields in which GIS is used (Rodrigue et al, 2006). Diverse areas of transportation, including high-way and rail-way infrastructure management, international shipping, airport management, fleet logistics, traffic management and intelligent transportation systems (ITS), transit bus and rail service planning, transportation modeling, supply chain modeling, and others, are applying GIS to their work (ESRI, 2003). The breadth of the field of integration of GIS and transportation system provides large opportunities for the development of new and innovative applications in transportation system of different transportation organizations (Curtin, 2003). Since GIS have a seamless relation with space and location, given that their main objective as a tool is to store, retrieve, and facilitate the analysis of spatial data (Goodchild and Janelle, 2004), they have become one of the most powerful tools to support transportation studies and applications. Capitalizing on this relationship both academics and practitioners have focused their attention on research/work that makes use of GIS in transportation applications.

Road transport in Nigeria (like in most countries of the world) is by far the most dominant mode of transportation, carrying well over $90 \%$ of passenger and freight traffic, and serving as a true backbone for Nigeria's economy (Transport Research Board, 2017). Because a well maintained road transport asset is very important for the economic development of the nation, Road Management Information System is a crucial for successful and sustainable management of road transport facilities. Geospatial data are foundation for relevant and critical information for planning, engineering, asset management, and operations associated with every transportation mode at all levels of government and administration (Transport Research Board, 2017). Nigeria has the largest road network in West Africa and the second largest south of the Sahara with roughly $108,000 \mathrm{~km}$ of surfaced roads in 1990 (67,112 miles) (Miller and Shaw, 2015). Out of this total, 30,000 kilometers (18,642 miles) were paved, 25,000 kilometers $(15,535$ miles $)$ were gravel, and 53,000 kilometers (32,935 miles) were unimproved earth. Much of the road system is in disrepair and barely useable. Massive traffic jams are very common in the large cities, there are also long delays in the movement of goods. Highway accidents and deaths are frequent, and have reached more than 30,000 and 8,000 , respectively. However, they are poorly maintained and are often cited as a cause for the country's high rate of traffic fatalities. In 2004 Nigeria's Federal Roads Maintenance Agency (FERMA) began to patch the 32,000-kilometre federal roads network, and in 2005 FERMA initiated a more substantial rehabilitation. With respect to the quality of overall infrastructure, Nigeria was ranked number 125 out of 142 countries, with a value of 3.0 ( 1.3 below the mean value). Cameroon was ranked at 122 and Ghana at 90 (TIO, 2014). With regard to road quality, Nigeria was ranked at 120 , with port infrastructure at 117 , railroad quality at 104 and air transport quality at 104 . There are almost $200,000 \mathrm{~km}$ of roads in Nigeria, $15 \%$ of them paved (2012). There are over 3,500 $\mathrm{km}$ of railway and much of the network is single track (TIO, 2014).

Currently, comprehensive record about the number and other important attributes (such as length, width, type, category, date of construction, expiry date, and last date of maintenance) of road transport infrastructure in most Nigerian cities and Katsina town inclusive are seriously lacking. The few available ones are mostly in analogue form (paper based) and scattered between different offices within the transport 
ministry and other related departments. This makes it difficult to manage, manipulate, retrieve and update the information. Additionally, information on uses/functions (if available) of transport facilities are unstructured and as a result makes it time-consuming for end-users to extract information about specific functions or uses of the facilities. Records (spatial and attributes) about other related transport infrastructures such as bridges, flyovers, culverts and underpasses is also necessary especially for planning and development purposes. Comprehensive database on road traffic signs, junctions and U-turns which are also very important safe transport system and for future and sustainable development are also lacking. Some of the related studies conducted includes Cortes et al., (2013); Herstein et al., (2011); ESRI. (2011); Id and Morshed, (2007); Anderson et al., (2010); Ryley et al., (2014); Loidl et al., (2016); Hasegawa, (2015); John, (2012); Strano et al., (2012); Indira et al., (2013).

In order to develop a functional and sustainable road transport management system, a comprehensive and digital GIS-based TIS is required to support decision-making process for sustainable urban development. This will enable the integration of spatial and attribute data of all available transport infrastructures. It will also provide for transport related data collection, integration, manipulation, analysis, spatial database design, and database queries in order to retrieve and update the information system whenever is necessary. This justifies the significance of this study.

\section{MATERIALS AND METHODS}

\section{Study Area}

Urban Katsina is the capital of Katsina State, it is located between latitude $12^{0} 45^{1} \mathrm{~N}$ and $13^{0} 15^{1} \mathrm{~N}$ and Longitude $7^{0} 30^{1}$ and $8^{0} 00 \mathrm{E}$. The location is at the extreme part of northern Nigerian, some $30 \mathrm{~km}$ from the Nigeria-Niger boarder. The city is administratively headed by an emir, with district and ward as sub units for administrative convenience. Urban Katsina comprises of two local government areas, Katsina and some part of Batagarawa Local Government areas (Zayyana 2010). The main ethnic groups are the Hausa's and Fulani's. the Fulani has primarily settled or semi-settled cattle herders, and sometimes with some limited crop production activities. The Hausa's are largely crop cultivators, but who also often keep some animals. A history of association and interaction between the two ethnic groups has led to merger of culture and tradition, mainly the unifying influence of Islam, the Hausa language and inter-marriages. In addition, other ethnic groups with lower but still significant important in Katsina towns social and economic development include Igbo, Yoruba, Nupe, Kanuri Tiv and others (Zayyana 2010).

\section{Population and Settlements}

Urban Katsina has a fairly large population, enjoys SubSahara African rate of population increase with average birth and deaths trates of $4.2 \%$ and $1.6 \%$ respectively (Zango, 2010). As of 1952 census, the population figure was 52,672 and rose to 223,644 in 1991 , by then it had already acquired the status of a state capital. The population figure after the 2006 census was recorded to be 327,376 (National Population Commission, 2006). The settlement pattern has characterized by two categories base on population density. The first category is the high to medium density settlement is which include the Cikin Birni (Old City) with their peripheral areas respectively. While the second category is the low-density settlement of Government Reservation Areas (GRA), Kofar Marusa, Low Cost and New Layout among other. The Cikin Birni which is the old city and the most densely populated area in the metropolis have a unique cultural setting that affects the people in the area. Most buildings are made up of mud and clay, closely packed together and surround with walls (Hassan, 2008)

\section{Land Use}

Land use in the study area is dominated by urban activities, such as residential, institutional, commercial and industrial land use, with small area mostly undeveloped for farming. Aside from major urban land use mentioned above, other land use such as livestock production and gathering are also carried out in the area. Residential area covers most part of the study area, different land uses such as commercial, institutional, and educational are all located within the residential areas. Sabuwar Unguwa extension is the major area functioning as industrial layout. Industries such as steel rolling, packaging, beverage processing etc are found in this area. Commercial activities happened to be growing very fast in the area. There are many smalls and major central market. The popular markets here are Katsina central market, Kofar Marusa markets and the old market (Tsohuwar Kasuwa). Also there are many department store shopping centers and supermarkets-where local, national and foreign commodities are sold. Institutional land uses can be found at various locations within urban Katsina. Tertiary institutions include Umaru Musa Yar'adua University, Fedral College of Education, Hassan Usman Katsina Polyethnic and School of Nursing and Midwifery in addition to numerous nursery/primary and secondary school both governmental and privately owned 


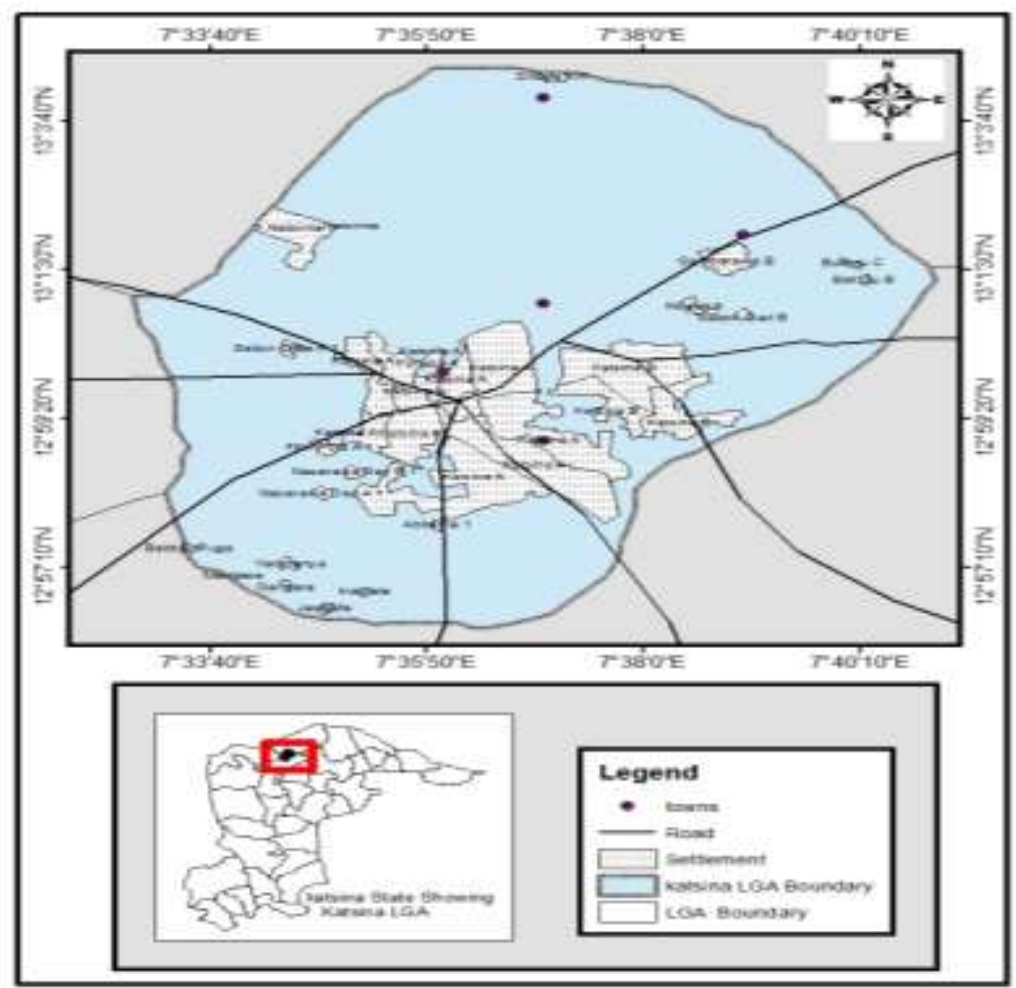

Figure 1: Katsina Local Government Area of Katsina State

Source: Dept of Geog, BUK) (2019)

\section{MATERIALS AND SOFTWARE USED}

The various materials and software used for data collection and analysis are summarized and presented in Table 1.

Table1: Materials and Software used

\begin{tabular}{|l|l|}
\hline Hardware/Software & Usage \\
\hline $\begin{array}{l}\text { Global Positioning System } \\
\text { GPS) }\end{array}$ & $\begin{array}{l}\text { Used for collecting the spatial attributes/coordinates (lat \& long) of road transport facilities to } \\
\text { enable spatial mapping using the GIS software }\end{array}$ \\
\hline Camera & $\begin{array}{l}\text { Remote Sensing sensor mounted on Techno K9 platform (8 mega pixel) was used for capturing } \\
\text { the images of the facilities in order to enable using hyper link to link the spatial data with the } \\
\text { images }\end{array}$ \\
\hline $\begin{array}{l}\text { HP Laptop Computer (windows 8, } \\
\text { processor: intel Pentium and } \\
\text { system) }\end{array}$ & HP Laptop was used for processing and analyzing all the data gathered for the study. \\
\hline Microsoft Word and Excel 2013 & $\begin{array}{l}\text { Used for compiling attribute information of the transport facilities and preparing locational data } \\
\text { for onward importing into the GIS environment. }\end{array}$ \\
\hline QGIS 3.8 & Used as for mapping, designing, analysis, querying, and creation of geodatabase for RTFMS. \\
\hline
\end{tabular}

\section{Types and Sources of Data}

Both spatial and attribute data about road transport infrastructures were collected using GPS, and also consulting records from the related ministries. Satellite images from Google earth and road transport map of Katsina, documents on culverts, bridges and flyovers of Katsina LGA were also obtained from the related ministries and departmnts. The overall data types and sources are summarized in Table 2. 
Table 2: Data types, sources and usage

Table 2: Data types, sources and usage
\begin{tabular}{|l|l|l|}
\hline Data required & Sources & Usage \\
\hline Road transport base map & $\begin{array}{l}\text { Ministry of Works Katsina } \\
\text { State }\end{array}$ & $\begin{array}{l}\text { Serve as basemap which was georeferenced and } \\
\text { digitize. Used to identify, characterize and delineate } \\
\text { the roads transport facilities for geospatial database } \\
\text { creation. }\end{array}$ \\
\hline Google Earth image & Google Applications, 2019 & $\begin{array}{l}\text { Used to update the analogue basemap from the } \\
\text { ministry. }\end{array}$ \\
\hline $\begin{array}{l}\text { Road information } \\
\text { Documents (attribute } \\
\text { data) }\end{array}$ & Ministry of Works Katsina State & $\begin{array}{l}\text { Provided the attribute data of the existing facilities to } \\
\text { be used for inventory creation and database } \\
\text { develpoment. }\end{array}$ \\
\hline $\begin{array}{l}\text { GPS and Camera } \\
\text { For collecting coordinates points of the infrastructures } \\
\text { and pictures for hyperlinking in order to see the nature } \\
\text { of some of the facilities. }\end{array}$ \\
\hline
\end{tabular}

\section{Methods of Data Analysis and Presentation}

Nearest Neighbor Analysis was conducted to determine the spatial distribution of road transport infrastructures within the study area. Three stages (conceptual, logical and physical design) were used in designing and building the Geodatabase. Spatial join and hyperlink were used to integrate the spatial and non-spatial data to create road and other facility layers so as to develop the GIS-based RTIMS. Hyperlink tool was used to integrate displays (pictures showing the nature or condition of an infrastructure) for proper management of the system. Series of spatial and attribute queries based on different criteria were used in demonstrating various methods of retrieving information from the database developed.

\section{RESULTS AND DISCUSSIONS}

This section presents and discussed the results from the analysis conducted under the following subheadings: Updated RTF types and characteristics, spatial distribution of roundabouts, RTF spatial database and RTF database queries.

\section{Updated RTF types and characteristics}

Figure 2 present the updated RTF map of Katsina Local Government and were characterized using various symbols layer properties in the QGIS software. The road were categories into three classes (the Primary, Secondary and Tertiary roads) and the roundabouts and bridges/culverts were represented as point feature using different symbols respectively. The figure provides synoptic view of all available RTF within the study area and their topological relationships.

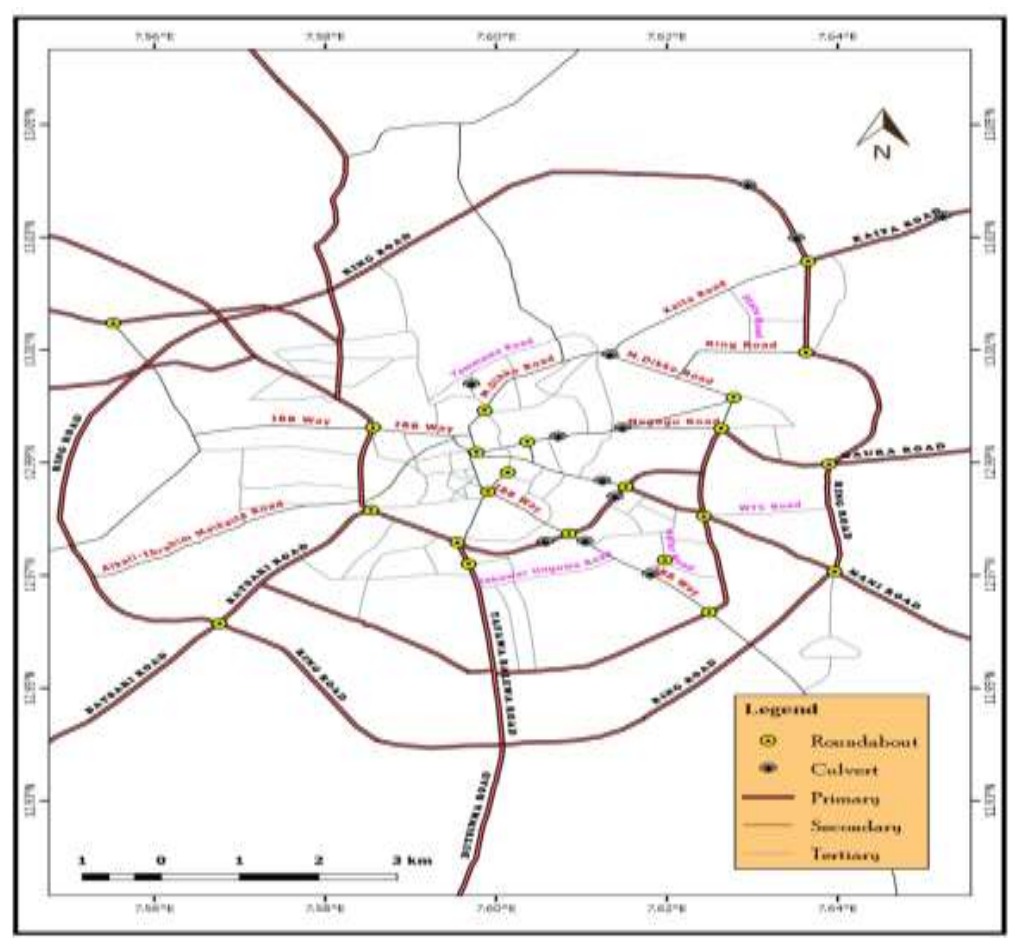

Figure 2: Road Transport Facilities in Katsina Local Government

(Source: Author's Analysis 2019)

Spatial Pattern of Roundabouts within Katsina LGA.

The distribution pattern of roundabouts in the study area was determined by Average Nearest Neighbor in QGIS 3.8 software interface. Figure 3 presented the average nearest neighbor summary for roundabouts in the study area. The result shows a dispersed distribution pattern of roundabouts in the area with nearest neighbor ratio of 1.340667 with critical value (z-score) of 2.914580 at 0.003562 level of significance (p-value). The dispersed pattern of roundabouts indicates low level of complexity in the transport system, while a clustered pattern signifies a complex transport system. 


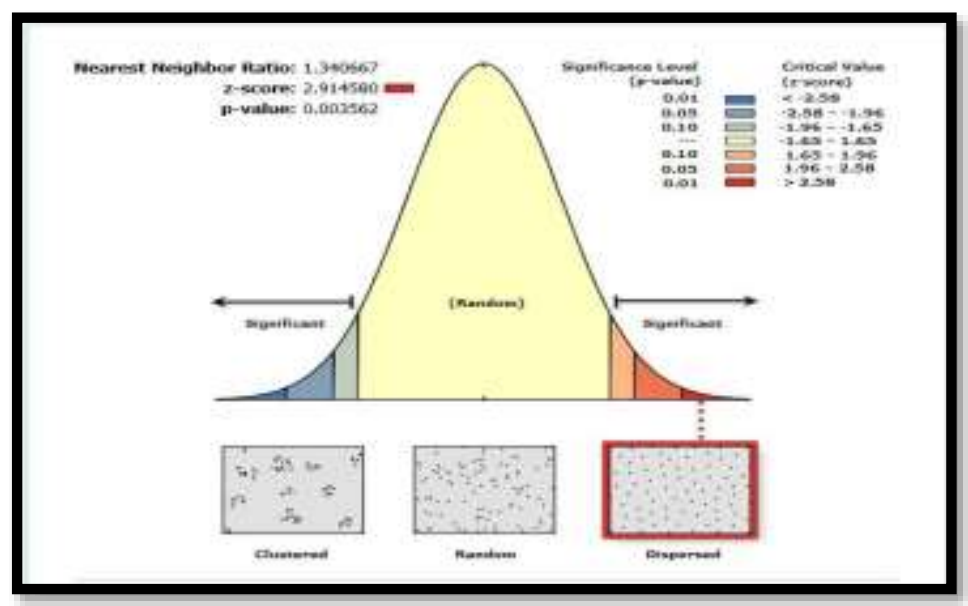

Figure 3: Distribution Pattern of Roundabout within Katsina LGA～(Source: Author's Analysis 2019)

RTF Spatial Database in Katsina LGA

The data collected in the form of spatial, non-spatial and photographs were used to develop a comprehensive geodatabase of transport facilities in the study area. The interphase from the software showing the attributes of various RTI is presented in figures 4-8. 
ROAD TRANSPORT INFORMATION...

Muhammad and Sulaiman

\begin{tabular}{|c|c|c|c|c|c|c|c|}
\hline Nane & Lerght M & Leogth(on) & Cariage & Lane & Surface & With $N$ S & Spesdint \\
\hline 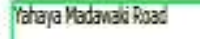 & 1559.53 & 1.58 & & & 4 Pared & 9,50 & Manh \\
\hline Thara Matandi Rasd & 122393 & 1.20 & & & 4 Pared & 19.60 & Dosinh \\
\hline Theria Matanai hasd & 1097.36 & 1.10 & & & 4 Paved & 19.60 & Dovenh \\
\hline Tafova Bdena Pload & 439.50 & 4.04 & & & 4 Pared & 9,80 & 30)/h \\
\hline StaéRolong Rad & 3071.79 & 3.07 & & & 4 Paned & 9.50 & $303 \mathrm{nh}$ \\
\hline Strif Abratman Wiay & $159 Q 31$ & 1.65 & & & 4 Pared & 19.62 & Dinth \\
\hline Ring Poad & 1322 & 2.13 & & & 4 Paved & 19.60 & Dobnh \\
\hline Fing Pad & 200.53 & 201 & & & 4 Paved & 9.60 & 302,h \\
\hline Ringhad & 3114.89 & 3.11 & & & 4 Pared & 9.50 & \$nh \\
\hline Ring Road & $3828 B 3$ & 383 & & & 4 Pared & 19.50 & Dongh \\
\hline Aing Poad & 7522.03 & 7.53 & & & 4 Paved & 19.60 & Dovinh \\
\hline Murtal Mhernot Way & 1697.40 & 1.70 & & & 4 Paned & 9.60 & Magh \\
\hline Murtabiatanned Waj & 1669.74 & 1.27 & & & 4 Pared & 960 & $30 \pi \mathrm{nh}$ \\
\hline Mutabiatamed Wia & 21002 & 291 & & & 4 Pared & 19,50 & 2007,h \\
\hline Mrtala Wharned Way & 16566.28 & 15.66 & & & 4 Paved & 19,63 & DDonh \\
\hline Karifood & 1255861 & 12.56 & & & 4 Pared & 9.60 & 305, \\
\hline Kate Pload & 915236 & 9.16 & & & 4 Pand & 9.50 & manh \\
\hline Jrain ShehuStena Wlay & 1016.23 & 102 & & & 4 Paied & 99.60 & Dornh \\
\hline Hessan Usren Rad & 21182 & & & & 4 Paved & 19.62 & Downh \\
\hline & & & & & & & \\
\hline Ousima Road & 780.71 & 730 & & & 4 Paved & 9,30 & 300,h \\
\hline Cara Rad & 466353 & & & & 4 Pared & 19.50 & $\$ 2 \pi n$ \\
\hline Darapoad- & 4231.14 & & & & 4 Proved & 1960 & Whin \\
\hline
\end{tabular}

Figure 4: Attributes of the Primary Roads

\begin{tabular}{|c|c|c|c|c|c|c|}
\hline Name & Length $(M)$ & lerght $(\mathrm{km})$ & Surface & Wisth $(M)$ & Lane & Speedint \\
\hline 1 Sabon Layi Rard & 1094.58 & 1.08 & Paved & 10.30 & & $46 \% \mathrm{~m} / \mathrm{h}$ \\
\hline , Ring Road & 1952.55 & 1.95 & Paved & 10.30 & & $460 \mathrm{knh}$ \\
\hline Alsnasegn Obasarip Road & 626.05 & 0.63 & Paved & 10.30 & & $460 \mathrm{kmh}$ \\
\hline 4. Nagogo Road & 2459.10 & 2.5. & Paved & 10.30 & & $46 \% \mathrm{mhh}$ \\
\hline M.Diko Road & 1775,10 & 1.7 & Paved & 10.30 & & $260 \mathrm{Kmhh}$ \\
\hline M.Dklo Foad & 2004.83 & 2.10 & Paned & 10.30 & & $460 \mathrm{knhh}$ \\
\hline M.Dko Foad & 806,00 & 0.89 & Paved & 10.30 & & $260 \mathrm{knhh}$ \\
\hline KataRosd & 3165.65 & 3.17 & Paved & 10.30 & & $26 \% \mathrm{Knh}$ \\
\hline Kabi Usman Road & 1546.24 & 1.55 & Paved & 10.30 & & $460 \mathrm{knhh}$ \\
\hline nd $^{\text {IBB Way }}$ & 1325.20 & 1.33 & Paved & 10.30 & & $460 \mathrm{knh}$ \\
\hline $11^{18 B \text { Way }}$ & 226226 & 2.36 & Paved & 10.30 & & $460 \mathrm{knhh}$ \\
\hline${ }_{12}$ IBBWay & 777.53 & 7.78 & Paved & 10.30 & & $460 \mathrm{Knh}$ \\
\hline${ }_{13}{ }^{1 B B a y}$ & 800.41 & 0.82 & Paved & 10.30 & & $260 \mathrm{Knh}$ \\
\hline $14^{I 8 B \text { Way }}$ & 1038,10 & 1.04 & Paved & 10.30 & & $460 \mathrm{knht}$ \\
\hline $15^{\text {IBD Way }}$ & 2312,48 & 2.31 & Paved & 10.30 & & $260 \mathrm{knhh}$ \\
\hline${ }_{16}$ Alaki-Jratin Malata Road & 5604.24 & 5.60. & Paved & 10.30 & & $26 \% \mathrm{Knh}$ \\
\hline \multirow{2}{*}{17} & 206271 & 2.06 & Paved & 10.30 & & $260 \mathrm{Knhh}$ \\
\hline & 6755 & & Pawad. & $\operatorname{nn} n$ & & 4 forkht. \\
\hline
\end{tabular}




\begin{tabular}{|c|c|c|c|c|c|c|}
\hline & Name & Lane & Width (M) & Speed Lmt & Length (M) & Length(Km) \\
\hline & Yarkutungu Road & 2 & 1.50 & $60 \mathrm{Km} / \mathrm{h}$ & 1076.19 & 1.08 \\
\hline$?$ & Yammawa Road & 1 & 1.50 & $60 \mathrm{Km} / \mathrm{h}$ & 3733.79 & 3.73 \\
\hline 3 & WTC Road & 2 & 1.50 & $60 \mathrm{Km} / \mathrm{h}$ & 1600.41 & 1.60 \\
\hline 4 & Waziri Zayyana Road & 2 & 1.50 & $60 \mathrm{Km} / \mathrm{h}$ & 1445.54 & 1.45 \\
\hline 5 & Unguwar Alkali Road & 2 & 1.50 & $60 \mathrm{Km} / \mathrm{h}$ & 659.83 & 0.66 \\
\hline 6 & Tsohowar Kasuwa Road & 2 & 1.50 & $60 \mathrm{Km} / \mathrm{h}$ & 609.64 & 0.61 \\
\hline 7 & State Road & 1 & 1.50 & $60 \mathrm{Km} / \mathrm{h}$ & 1294.59 & 1.29 \\
\hline 8 & State Road & 2 & 1.50 & $60 \mathrm{Km} / \mathrm{h}$ & 716.88 & 0.72 \\
\hline 9 & State Road & 1 & 1.50 & $60 \mathrm{Km} / \mathrm{h}$ & 940.16 & 0.94 \\
\hline 10 & Shararrar Pile Road & 2 & 1.50 & $60 \mathrm{Km} / \mathrm{h}$ & 1153.30 & 1.15 \\
\hline 1 & Sarkj Dikko Road & 2 & 1.50 & $60 \mathrm{Km} / \mathrm{h}$ & 1275.78 & 1.28 \\
\hline 12 & Sabuwar Unguwa Road & 1 & 1.50 & $60 \mathrm{Km} / \mathrm{h}$ & 1853.16 & 1.85 \\
\hline 13 & Sabowar Kasuwa Road & 1 & 1.50 & $60 \mathrm{Km} / \mathrm{h}$ & 849.34 & 0.85 \\
\hline 14 & Medical Centre Road & 1 & 1.50 & $60 \mathrm{Km} / \mathrm{h}$ & 1570.78 & 1.57 \\
\hline 15 & Lawrence Onoja Road & 2 & 1.50 & $60 \mathrm{Km} / \mathrm{h}$ & 1552.24 & 1.55 \\
\hline 16 & Korau Street & 2 & 1.50 & $60 \mathrm{Km} / \mathrm{h}$ & 1024.06 & 1.02 \\
\hline 17 & Kankia Road & 2 & 1.50 & $60 \mathrm{Km} / \mathrm{h}$ & 454.40 & 0.45 \\
\hline 18 & Kafur Road & 2 & 1.50 & $60 \mathrm{Km} / \mathrm{h}$ & 1382.14 & 1.38 \\
\hline 19 & Jibia Road & 2 & 1.50 & $60 \mathrm{Km} / \mathrm{h}$ & 579.81 & 0.58 \\
\hline 20 & Guga Road & 1 & 1.50 & $60 \mathrm{Km} / \mathrm{h}$ & 958.27 & 0.96 \\
\hline 21 & Dutsinma Street & 1 & 1.50 & $60 \mathrm{Km} / \mathrm{h}$ & 626.03 & 0.63 \\
\hline 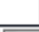 & Daki Tara Road & 1 & 1.50 & $60 \mathrm{Km} / \mathrm{h}$ & 767.18 & 0.77 \\
\hline
\end{tabular}

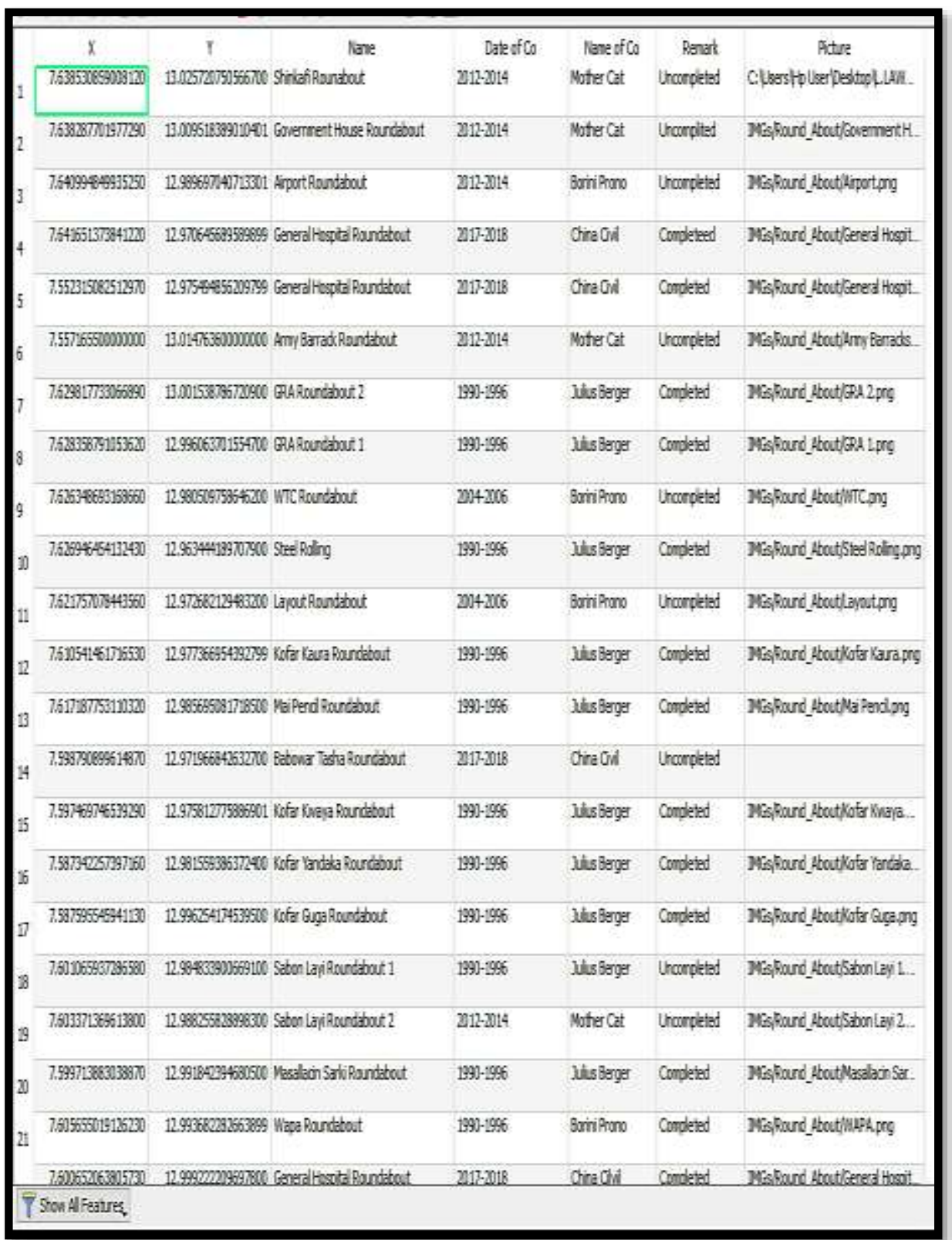




\begin{tabular}{|c|c|c|c|c|c|c|c|c|c|}
\hline Nane & $x$ & $Y$ & Wisth $(0)$ & Nane of $C O$ & Date of $\mathrm{Co}$ & Naterial & Road Type & Renakk & Piture \\
\hline 1 Kofor Sayri & 7.61532955 & 13.0039932 & 10.30 & Juss Berger & 1990-1996 & Concete & State Road & Good & DNGs, Cowerthof. \\
\hline${ }_{2}$ Kofor Duri & 7616799 & 129960144 & 10.30 & Jus Berger & 1990-1996 & Concrete & State Road & Good & \\
\hline 3 Kerau Yar Gada & 7.60926023891421 & 129944661963399 & 10.30 & Bocrifirono & & Concete & State Road & Good & DGs/Othert/fas. \\
\hline 4 Thaya Madak 3 & 7.62009943 & 129700799 & 19.30 & Jisus Berger & $1990-1996$ & Concete & State Poad & Good & DGsolowert/fa... \\
\hline 5 Yahaya Madali 4 & 7512426 & 129758658 & 19.30 & Jitus Perger & 1990-1996 & Concete & State Road & Good & IMSs, Colvert//ia. \\
\hline 6 Kofor Kaura & 7.6077446 & 129757758 & 10.30 & 1) Jus Beger & 1990-1996 & Concete & State Road & Good & DGsjodvert/Kof. \\
\hline 7 Yammana & 759910652384554 & 13.0037839534333 & 10.30 & Mother Cat & $2012-2014$ & Concuete & State Pood & Good & MGSOAhiert//a. \\
\hline 8 LarbunSarki & 7.6195967 & 129837854 & 10.30 & Jihs Berger & 1990-1996 & Concete & State Poad & Good & DNGS/Odhertla. \\
\hline 9 Lanbun Sark 2 & 7.6144431 & 12.9866055 & 10.30 & Jitus Berger & 1990-1996 & Concete & State Road & Good & MGs;chert/la. \\
\hline 10 Thaya Madak 2 & 763717375429686 & 13.0296588773802 & 19.30 & Mother Cat & $2012-2014$ & Concete & State fioad & Good & DGSjodwert/fa. \\
\hline 11 Yataya Madde 1 & 7631472 & 130350864 & 19.30 & Mother Cat & $2012-2014$ & Concrete & State Pload & Good & MGs/Otiert//a. \\
\hline 12 Strikaf & 765431549190957 & 13.0336088700174 & 10.30 & Jus Berger & $1990-1996$ & Concete & State Road & Fair & DNGs/Odvert/Shi. \\
\hline
\end{tabular}

Figure 8: Attributes of some culverts

(Source: Author's Analysis 2019)

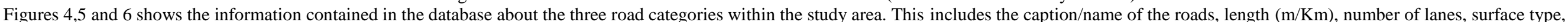

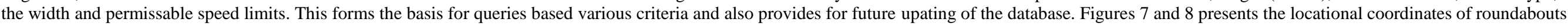
and culverts/bridges, their captions, date of construction, contractors, status (completed or not) and the pictures displaying their present status.

\subsection{Identification of RTI using Identify Too}

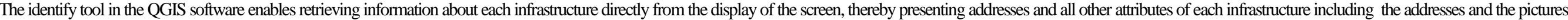
Figures 9-13 presents the use of identify/select tool to retrieve information about various infrastructures within the study area, and hyperlink to join the attributes of a facility with its picture. 

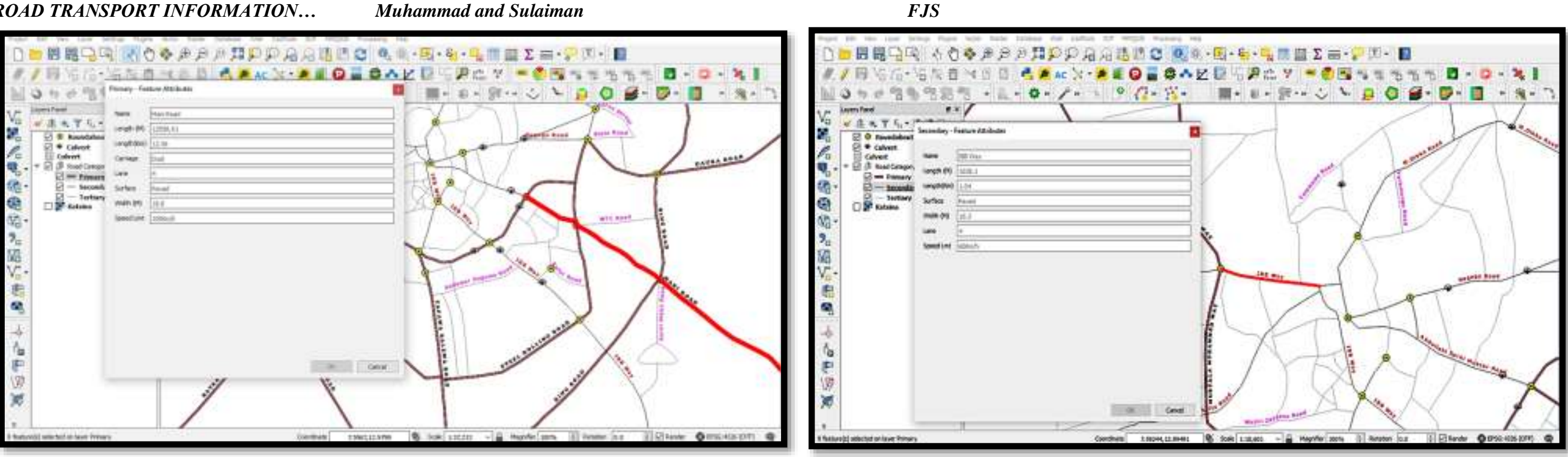

Figure 9: Primary Road Identification in Katsina LGA

Figure 10: Secondary Road Identification in Katsina LGA
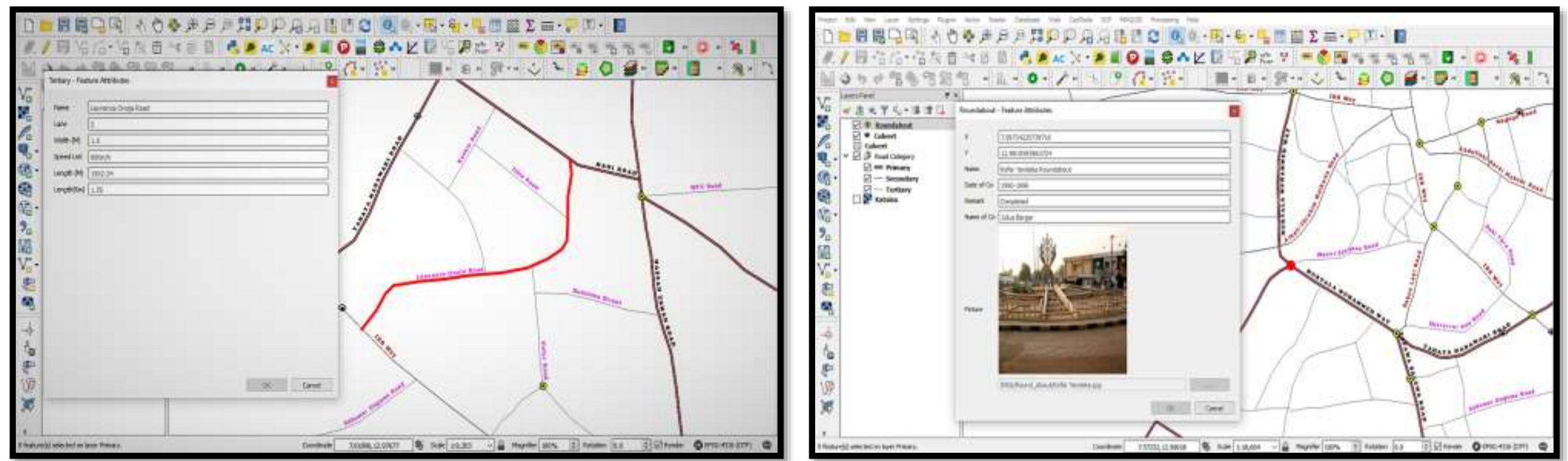


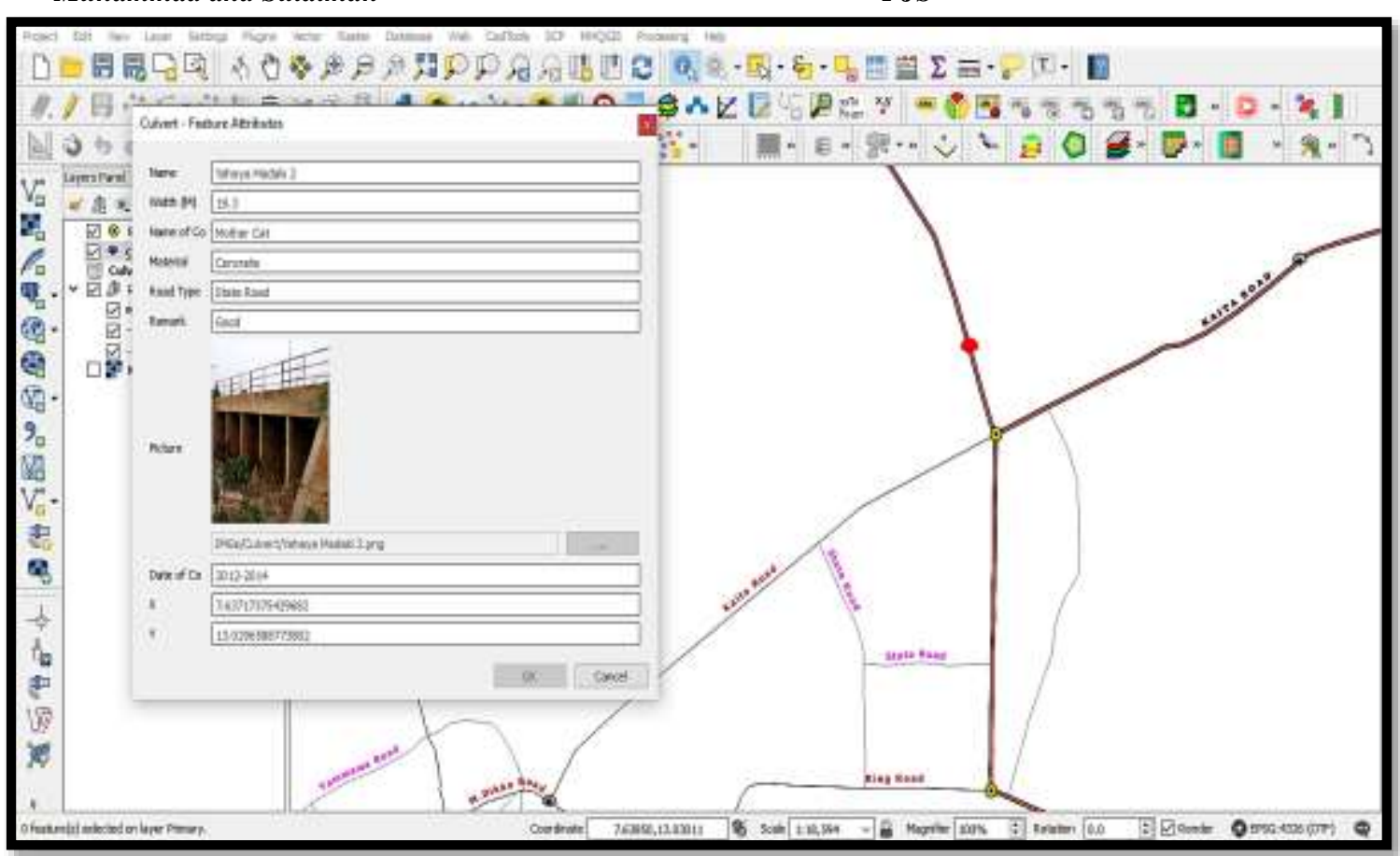

Figure 13: Major Culver/Bridge Identification in Katsina Local Government

\section{RTIS Queries}

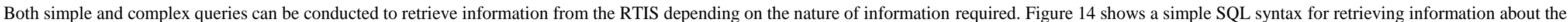

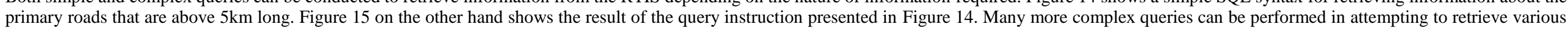
information for the database created. 


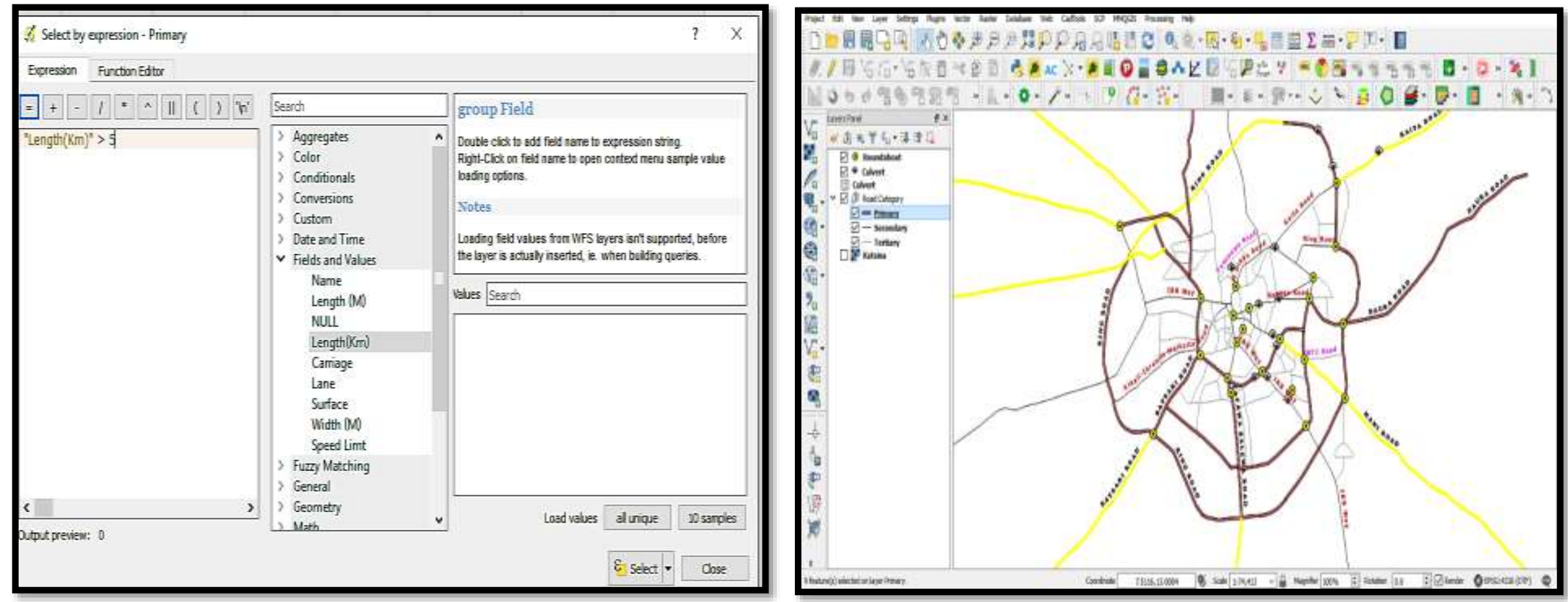

Figure 14: SQL syntax for retrieving Primary Roads above 5km length

Figure 15: Showing Primary Roads that are more than $5 \mathrm{Km}$ in Length 


\section{CONCLUSION AND RECOMMENDATIONS}

The study concluded that the role of GIS technology in RTFIM cannot be over emphasized as it is one of the sophisticated technology that enables road traffic infrastructure data capture, storage, retrieval updating, manipulation and simulation for efficient monitoring and optimum management. It is therefore recommended that the departments responsible for monitoring and managing RTI in Katsina Local government should embrace this technology for sustainable transport development within the study area.

\section{REFERENCES}

Anderson, R. E., Brunette, W., Johnson, E., Lustig, C., Poon, A., Putnam, C., ... Borriello, G. (2010). Experiences with a transportation information system that uses only GPS and SMS. ACM International Conference Proceeding Series. https://doi.org/10.1145/2369220.2369223

Cortes, J. A. Z., Serna, M. D. A., \& Gomez, R. A. (2013). Information systems applied to transport improvement. DYNA (Colombia), 80(180), 77-86.

Curtin, K., Noronham, V., Goodchild, M. and Grise, S., (2003). “ArcGIS Transportation GIS Model”, ESRI.

ESRI (2003). Understanding GIS - The Arc-Info Method. A Workbook on GIS by Environmental System Research Institute Redlands CA, USA.

ESRI. (2011). GIS for Transportation Infrastructure Management. https://doi.org/10.1016/j.micron.2011.03.007

Goodchild, M. F. (2004). GIS and transportation: status and challenges. GeoInformatica 4(2): PP 127-139. P. 336.

Hasegawa, T. (2015). Chapter 5-Intelligent Transport System. Traffic and Safety Science - Interdiciplinary Wisdom of IATSS, $212 . \quad$ Retrieved from http://www.iatss.or.jp/en/publication/commemorativepublication/

Herstein, L. M., Filion, Y. R., \& Hall, K. R. (2011). Discussions and Closures Discussion of " Evaluating Environmental Impact in Water Distribution System Design " Closure to "Evaluating Environmental Impact in Water Distribution System Design " by. 15(3), 52-53. https://doi.org/10.1061/(ASCE)1076-0342(2009)15

Id, S. A., \& Morshed, D. (2007). Transport Information System ( TIS ) Transport Information System ( TIS ). (May), $1-44$.
Indira, A.P., College, G., Ganorkar, R. a, Rode, P. I., \& Bhambulkar, A. V. (2013). Application Of Gis In Transportation Engineering. International Journal of Engineering, 3(2), 540-542.

John A. V. (2012). Best Practices in Geographic Information Systems-Based Transportation Asset Management. Argumentation, (January), 71. https://doi.org/10.1080/10903120601023461

Loidl, M., Wallentin, G., Cyganski, R., Graser, A., Scholz, J., \& Haslauer, E. (2016). GIS and transport modelingstrengthening the spatial perspective. ISPRS International Journal of Geo-Information, 5(6). https://doi.org/10.3390/ijgi5060084

Miller H. J. and Shaw S. (2015). Geographic Information System fro Transportation in the $21^{\text {st }}$ Century. Geography Compass, Volume 9, Issue 4, pg 180-189, https://doi.org/10.1111/gec3.12204.

Rodrigue, J. P., Comtois, C, and B. and Slack, B. (2006). The Geography of Transport Systems, Routledge, New York. P. 362 .

Ryley, T. J., Stanley, P. A., Enoch, M. P., Zanni, A. M., \& Quddus, M. A. (2014). Investigating the contribution of Demand Responsive Transport to a sustainable local public transport system. Research in Transportation Economics, 48, 364-372. https://doi.org/10.1016/j.retrec.2014.09.064

trano, E., Nicosia, V., Latora, V., Porta, S., \& Barthélemy, M. (2012). Elementary processes governing the evolution of road networks. Scientific Reports, 2, 1-8. https://doi.org/10.1038/srep00296

Transport Research Board (2017). Guidelines for the designing and operation of road management systems. Overseas Road Note 15. Department for Information Development 94 Victoria Street. London, SWIE 5JL

T I O (2014). Transport Infrastructure Organization in Nigeria. Nexus Strategic Partnerships Limited, (C) 2014.

Winter, S., Sester, M., Wolfson, O. and Geers, G. (2010). Towards a computational transportation science. SIGMOD Record 39, pp. 27-32.

Zayyana, Y. I. (2010). Some Aspects of Urban Farming in Urban Katsina, Katsina State. An unpublished Msc. Thesis submitted to the department of geography, Bayero University, Kano. 